\title{
Studi evaluatif tingkat kompetensi guru pendidikan jasmani olahraga dan kesehatan
}

\section{Evaluative study of physical education, sport, and health teachers' competency level}

\author{
Wahyu Dwi Prasetyo ${ }^{1}$, Suroto $^{2}$, \& Anung Priambodo ${ }^{3}$ \\ 1,2,3 Department of Sports Education, Postgraduate Program, Universitas Negeri \\ Surabaya, Jl. Lidah Wetan, Surabaya, East Java Province, 60213, Indonesia
}

Received: 7 May 2019; Revised: 4 November 2019; Accepted: 3 March 2020

\begin{abstract}
Abstrak
Penelitian ini bertujuan untuk mengetahui bagaimanakah tingkat kompetensi guru yang sebelumnya menggunakan Uji Kompetensi Guru (UKG) dengan model penilaian diri sendiri disertai bukti fisik terlepas dari tuntutan jawaban yang disediakan serta tingkat kompetensi dengan berdasarkan masa kerja dari guru Pendidikan Jasmani Olahraga dan Kesehatan (PJOK) Sekolah Dasar (SD). Penelitian ini merupakan jenis penelitian evaluatif yang menggunakan pendekatan penelitian deskriptif kuantitaif model Goal Oriented Evaluation. Hasil Uji Kompetensi Guru (UKG) berhubungan sangat kuat dan signifikan terhadap pengukuran kadar keguruan serta dapat digunakan sebagai alternatif pengukuran tingkat kompetensi guru. Tingkat kompetensi berdasarkan hasil pengukuran kadar keguruan yang termasuk dalam kategori biasa sebanyak 9 orang, kategori baik termasuk 36 orang, sedangkan untuk guru PJOK yang termasuk dalam kategori hebat sebanyak 7 orang. Analisis masa kerja menyebutkan bahwa ada pengaruh yang signifikan antara masa kerja dengan tingkat kompetensi, sehingga dapat disimpulkan bahwa semakin tinggi masa kerja semakin rendah tingkat kompetensi guru. Namun demikian, sumberdaya yang dilibatkan dalam penelitian ini masih mempunyai kekurangan, hal ini terbukti dengan kurangnya pemahaman untuk memberikan penjelasan bukti fisik sesuai dengan pilihan jawaban yang dipilih.
\end{abstract}

Kata kunci: tingkat kompetensi guru, uji kompetensi guru, masa kerja.

\begin{abstract}
This study aims to conclude Elementary School Physical Education, Sport, and Health teachers' competency level employing Teacher Competency Test (UKG) with a self-assessment model along with physical evidence, without the pressure of the provided answers, as well as to assess the competency level based on teachers' length of service. Likewise, this research is an evaluative research using a quantitative descriptive research approach of Goal Oriented Evaluation. Teacher Competency Test (UKG) results are strongly and significantly related to teachers' proficiency measurements as well as can be used as an alternative measurement of teacher competency levels. Hence, based on the measurement results, 9 teachers are in the fair level, 36 teachers are in the good levels, and 7 teachers are in the excellent level. The analysis of teachers' length of service states a significant influence between the length and the competence level. Hence, the conclusion of the analysis is the longer the length of service, the lower
\end{abstract}

Correspondence author: Wahyu Dwi Prasetyo, Universitas Negeri Surabaya, Indonesia.

Email:wahyupraz18@gmail.com

(c) (i) (2)

Jurnal SPORTIF: Jurnal Penelitian Pembelajaran is licensed under a Creative Commons

Attribution-ShareAlike 4.0 International License. 
the teachers' competency level. However, the involved resources in this study have shortcomings which is evidenced by the lack of understanding to provide an explanation of physical evidence in accordance with the chosen answers.

Keywords: teachers' competency level, teacher competency test (ukg), length of service.

\section{PENDAHULUAN}

Guru adalah ujung tombak dalam proses belajar mengajar, karena gurulah yang memegang peranan penting dalam membuat siswa mengerti dan paham mengenai mata pelajaran yang diajarkan. Sebagai seorang tenaga pendidik yang diakui sebagai seseorang yang profesional juga selalu dituntut untuk mengembangkan diri sejalan dengan kemajuan ilmu pengetahuan, teknologi, dan seni (Fathurrohman \& Suryana, 2012). Peningkatan mutu kompetensi sesorang guru terus dilakukan oleh pemerintah, oleh karena itulah pemerintah membuat tuntutan tentang Uji Kompetensi Guru (UKG) yang setiap tahun dituntut dengan standar tertentu (lihat gambar 1).

\begin{tabular}{|c|c|c|c|c|}
\hline Rerata & Rerata & Rerata & Rerata & Rerata \\
\hline$U K G=55$ & UKG $\equiv 65$ & $\mathrm{UKG}=70$ & $U K G=75$ & $\mathrm{UKG}=80$ \\
\hline $\mathrm{PKG} \equiv 75$ & $P K G=75$ & $P K G=75$ & $P K G=75$ & $\mathrm{PKG} \equiv 75$ \\
\hline 2015 & 2016 & 2017 & 2018 & 2019 \\
\hline
\end{tabular}

Gambar 1. Standar kelulusan UKG

Hasil UKG yang dilakukan pada tahun 2015 nilai yang didapatkan masih kurang dari harapan, yakni hanya dengan rata-rata 53,05 dari standar yang ditetapkan yaitu 55 (lihat gambar 1). Pencapaian rerata yang memenuhi standar yang ditetapkan pemerintah hanya 7 propinsi di Indonesia, yakni: DI Yogyakarta $(62,36)$, Jawa Tengah $(58,93)$, DKI Jakarta $(58,36)$, Jawa Timur $(56,71)$, Bali $(55,92)$, Jawa Barat $(55,15)$ dan Bangka Belitung $(55,10)$. Berdasarkan data pada tersebut, dapat diketahui bahwa tingkat kompetensi guru masih kurang dari harapan pemerintah, UKG yang seharusnya dilaksanakan setiap tahun untuk mengetahui tingkat kompetensi guru hanya sampai pada tahun 2015.

Solusi mengatasi rendahnya kualitas sumber daya manusia di Indonesia, perlu peningkatan kualitas dalam bidang pendidikan, utamanya 
guru sebagai poros pendidikan (Wahyono, 2016). Maka dari pendapat tersebut dibutuhkan sebuah standar mutu dalam melaksanakan profesi guru oleh pemerintah, oleh karena itu UKG dilaksanakan setiap tahun secara bertahap, memantau kinerja guru dari segi kompetensi, merencanakan untuk perbaikan pendidikan dan profesional seorang guru. Permintaan akan guru 'berkualifikasi tinggi' perlahan tapi pasti digantikan oleh guru yang sangat efektif dalam pembelajaran (Rink, 2013).

Kondisi dan situasi yang ada menjadi alasan setiap guru memiliki perbedaan dalam penguasaan kompetensi yang ditentukan (Kementerian Pendidikan dan Kebudayaan Direktorat Jendral Guru dan Tenaga Kependidikan, 2015). Hal tersebut menjadi alasan bahwa pelaksanaan UKG terhadap penguasaan kompetensi guru setiap jenjang pendidikan berbeda, seperti penguasaan kompetensi guru kelas Sekolah Dasar (SD) dengan guru mata pelajaran Pendidikan Jasmani Olahraga dan Kesehatan (PJOK) dalam lingkup SD itu pasti berbeda meskipun dalam satu jenjang pendidikan. Membangun profesionalisme guru ada tiga pilar menjadi "soko guru" profesi guru, yaitu: (1) prestise sosial yang berwujud pengakuan dan penghargaan dari masyarakat, (2) prestise material dalam bentuk jaminan imbalan jasa dan perlindungan profesi baik oleh masyarakat maupun pemerintah, (3) prestise profesional dengan ciri kendala layanan program pendidikan di lapangan dengan titik berat pada penugasan kompetensi (Rosmawaty, 2016).

Pada awal pelaksanaan UKG tahun 2015 nilai rerata yang harus dicapai adalah 55, tahun 2016 target dari rerata yang ditetapkan meningkat menjadi 65, tahun 2017 juga meningkat dari tahun sebelumnya menjadi 70, tahun 2018 juga meningkat menjadi 75, dan pada tahun 2019 meningkat menjadi 80 . Guru diharapkan dapat mengatasi tuntutan seperti itu karena dianggap sebagai salah satu kompetensi profesional mereka (Snopek \& Moravcikova, 2017). Peningkatan nilai rerata UKG yang semakin tahun semakin meningkat ini jelas menjadi tujuan pemerintah untuk meningkatkan mutu profesionalisme seorang guru untuk dapat meningkatkan mutu pendidikan, hal tersebut merupakan cara produktif 
untuk mengubah model defisit pengetahuan subjek guru menjadi pengalaman positif dengan potensi yang cukup besar untuk pengembangan kompetensi (Heywood \& Parker, 2010). Masa kerja juga akan menjadi pertimbangan bagaimana pemerintah akan melakukan pengembangan atau memantau kompetensi guru untuk mencapai tujuan dari pendidikan nasional. Fakta yang ada dilapangan yang terjadi adalah semakin lama masa kerja, semakin turun kompetensinya, baik komptensi pedagogik, profesional, kepribadian maupun sosial (Maksum, 2009).

Hasil penelitian yang dilakukan terdahulu menunjukkan bahwa guru kurang memiliki kompetensi dasar yang baik sehingga menyebabkan rendahnya nilai UKG dan indikator kemampuan literasi guru merupakan faktor yang memengaruhi rendahnya nilai UKG (Kusumawati, 2017). Berdasarkan hasil penelitian terdahulu harus dilakukan pemantauan kompetensi guru secara berkala, sehingga dapat diketahui faktor apa saja yang menjadi kelemahan dalam kompetensi guru.

Meskipun pemerintah telah membuat instrumen UKG secara formal dan berkala, namun selain tidak bisa digunakan sehari-hari oleh mahasiswa dan guru, jangkauannya pun hanya mengukur kompetensi pedagogik dan profesional saja. Oleh karena itu dibutuhkan alat ukur kompetensi yang valid dan praktis yang menjangkau 4 kompetensi (pedagogik, profesional, kepribadian, dan sosial) untuk keperluan seharihari guru maupun calon guru serta untuk keperluan penelitian. Realitas bukti fisik dan kesesuaian antara bukti fisik dengan kategori jawaban menentukan validitas jawaban menjadi penentu utama kualitas proses dan hasil pembelajaran (Suroto, 2016). Berdasarkan hal tersebut maka dilakukan penelitian dengan menggunakan instrumen kadar keguruan. Pemahaman UKG belum sepenuhnya dipahami sebagai media untuk penilaian diri, akibatnya guru cenderung menanggapinya sebagai tes sehingga jawaban yang diberikan hanya mengacu pada teori (Jatmika, Hariono, Purwanto, \& Setiawan, 2017). Penelitian ini dilakukan untuk mengetahui apa saja yang dilakukan dengan dirampungkannya bukti fisik. Penelitian ini diharapkan memberikan jawaban sesuai dengan keadaan 
nyata yang dialami oleh masing-masing guru di sekolah bukan hanya memberikan jawaban yang mengacu pada teori.

\section{METODE}

Penelitian ini merupakan jenis penelitian evaluatif yang menggunakan pendekatan penelitian deskriptif kuantitatif, untuk mengetahui bagaimana tingkat kompetensi guru melalui tingkat pengukuran yang dilakukan dengan menggunakan angket kadar keguruan serta pembandingan hasil dari kuisoner dengan hasil UKG yang terakhir kali dimiliki oleh pihak terkait selaku pihak yang berwenang dalam mempunyai data tersebut. Pelaksanaan pengukuran kadar keguruan dilakukan pada guru PJOK Sekolah Dasar di Kecamatan Pogalan dan Kecamatan Bendungan di Kabupaten Trenggalek selama bulan April-Mei 2018.

\section{Subjek Penelitian}

Subjek penelitian ini sebanyak 52 orang guru PJOK (27 guru PJOK SD di Kecamatan Pogalan dan 25 orang guru PJOK SD di Kecamatan Bendungan). Seluruh guru baik yang berstatus sebagai Pegawai Negeri Sipil (PNS) dan Guru Tidak Tetap (GTT) menjadi subjek pengukuran kadar keguruan, baik yang sudah pernah mengikuti ataupun yang belum pernah Uji Kompetensi Guru (UKG).

\section{Instrumen Penelitian}

Instrumen penelitian yang digunakan adalah kuisoner kadar keguruan PJOK. Kadar keguruan PJOK yang digunakan untuk mengukur tingkat kompetensi dengan aturan penilaian kelayakan menggunakan kategori kadar keguruan (Suroto, 2016) dengan rentang nilai 0\%-100\% (lihat tabel 1). 
Tabel 1. Skala Kadar Keguruan PJOK

\begin{tabular}{ccc}
\hline Kategori & Rentang & Kategori \\
\hline 1 & $0.0 \%<20.0 \%$ & Buruk \\
2 & $20.0 \%<40.0 \%$ & Kurang \\
3 & $40.0 \%<60.0 \%$ & Biasa \\
4 & $60.0 \%<80.0 \%$ & Baik \\
5 & $80.0 \%<100.0 \%$ & Hebat \\
\hline
\end{tabular}

(Suroto, 2016)

Hasil dari pengukuran kadar keguruan PJOK akan divalidasi jawaban dari deskripsi bukti fisik apakah sesuai dengan nilai yang dipilih oleh guru PJOK yang mengisi jawaban tersebut secara mandiri, jika nilai yang diisikan tidak sesuai dengan jawaban deskripsi bukti fisik, maka validator akan mengubah nilai sesuai dengan deskripsi bukti fisik yang telah dituliskan oleh guru tersebut.

\section{Teknik Analisis Data}

Teknik analisis data yang digunakan dalam penelitian ini adalah statistik deksriptif dikarenakan penelitian populasi dengan sasaran seluruh guru PJOK di Kecamatan Pogalan dan Kecamatan Bendungan. Hal ini sejalan dengan penelitian yang ditujukan pada populasi sudah pasti menggunakan statistik deskriptif dalam teknik analisis (Sugiyono, 2014).

\section{HASIL DAN PEMBAHASAN}

Hasil

Sesuai dengan tujuan dalam penulisan artikel, hasil penelitian ini ditujukan untuk mengetahui tiga hal, yaitu: (1) hubungan antara data hasil UKG dengan hasil pengukuran kadar keguruan PJOK; (2) mengetahui tingkat kompetensi melalui masa kerja; dan (3) mengetahui tingkat kompetensi guru PJOK melalui pengukuran kadar keguruan terhadap 52 orang guru PJOK di Kecamatan Pogalan dan Kecamatan Bendungan Kabupaten Trenggalek. Berdasarkan hasil uji korelasi Spearman dapat diketahui bahwa hubungan antara data hasil UKG dengan data pengukuran kadar keguruan didapatkan hasil correlation coefficient sebesar 0,858 pada 46 orang guru PJOK yang sudah mengikuti UKG dan pegukuran kadar keguruan. Hasil tersebut termasuk dalam kategori 
sangat kuat, artinya ada hubungan yang signifikan antara hasil UKG dan pengukuran kadar keguruan (lihat ditabel 2).

Tabel 2. Hasil Uji Korelasi Spearman antara Hasil UKG dengan Kadar Keguruan PJOK

\begin{tabular}{|c|c|c|c|c|}
\hline \multicolumn{5}{|c|}{ Correlations } \\
\hline & & & Nilai_UKG & Pengukuran_Kadar \\
\hline & & & & Keguruan \\
\hline \multirow{6}{*}{$\begin{array}{l}\text { Spearman's } \\
\text { rho }\end{array}$} & \multirow{3}{*}{ Nilai_UKG } & Correlation Coefficient & 1,000 & ,858* \\
\hline & & Sig. (2-tailed) & . & ,000 \\
\hline & & $\mathrm{N}$ & 46 & 46 \\
\hline & \multirow{3}{*}{$\begin{array}{l}\text { Pengukuran_Kadar_ } \\
\text { Keguruan }\end{array}$} & Correlation Coefficient &, $858^{* *}$ & 1,000 \\
\hline & & Sig. (2-tailed) & , 000 & . \\
\hline & & $\mathrm{N}$ & 46 & 46 \\
\hline
\end{tabular}

Berdasarkan tabel 2, dapat diketahui bahwa jumlah guru yang tidak mengikuti UKG tahun 2015 berjumlah 6 orang dengan kategori pengukuran 5 orang berada dalam kategori sebagai guru PJOK yang baik dan 1 orang berada dalam kategori hebat, dengan rata-rata kategori 4 sejumlah 74,6 dan kategori 5 sejumlah 83 . Standar deviasi sejumlah 2,51 untuk kategori 4 dan 0 untuk kategori 5 yang berarti data tersebut homogen karena hanya berjumlah 1 (lihat tabel 3).

Tabel 3. Deskripsi Data Guru yang Tidak Mengikuti UKG tahun 2015

\begin{tabular}{|c|c|c|c|c|c|c|}
\hline \multirow{2}{*}{ Kadar Keguruan } & \multicolumn{5}{|c|}{ Tingkat Pengukuran Kadar Keguruan } & \multirow{2}{*}{ Total } \\
\hline & 1 & 2 & 3 & 4 & 5 & \\
\hline$N$ & - & - & - & 5 & 1 & 6 \\
\hline Mean & - & - & - & 74,6 & 83 & 157,6 \\
\hline Std. Dev. & - & - & - & 2,51 & 0 & 2,51 \\
\hline Minimum & - & - & - & 71 & 83 & 154 \\
\hline Maksimum & - & - & - & 78 & 83 & 161 \\
\hline
\end{tabular}

Selanjutnya, pembahasan untuk tingkat kompetensi guru pada tabel 3 dilakukan dengan menggunakan pengukuran kadar keguruan data menunjukkan bahwa guru PJOK yang termasuk dalam kategori buruk $0 \%$ ( 0 orang), kategori kurang $0 \%$ ( 0 orang), kategori biasa sebanyak $17,30 \%$ (9 orang), untuk guru PJOK yang termasuk dalam kategori baik termasuk $62,20 \%$ (36 orang), sedangkan untuk guru PJOK yang termasuk dalam kategori hebat sebanyak $13,50 \%$ (7 orang) dari total 52 guru PJOK SD di 
Kecamatan Pogalan dan Kecamatan Bendungan Kabupaten Trenggalek (lihat gambar 2).

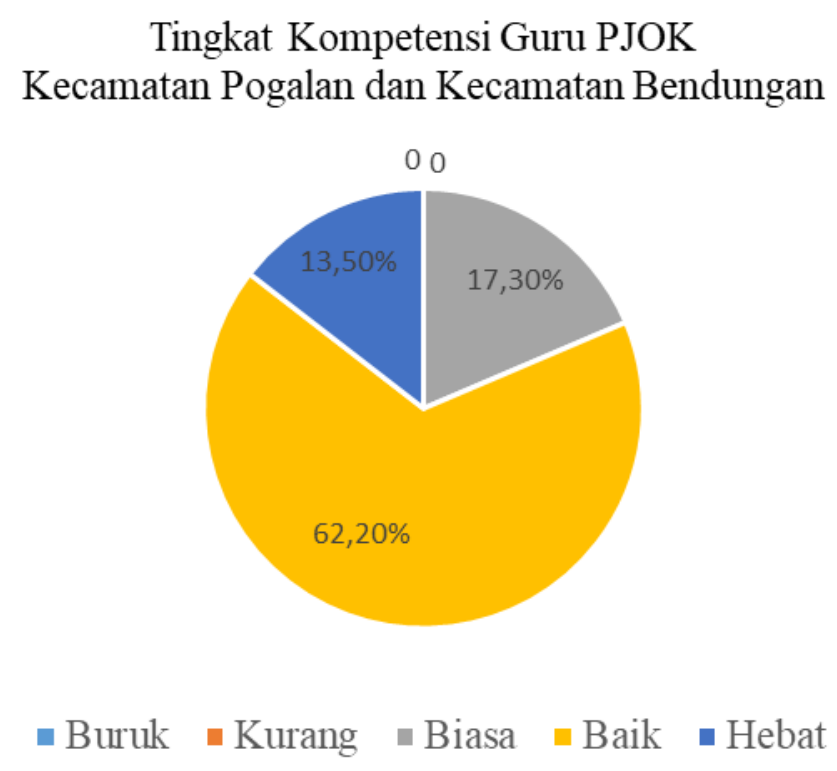

Gambar 2. Tingkat Kompetensi Guru PJOK Kecamatan Pogalan dan Kecamatan Bendungan

Hasil yang terakhir adalah masa kerja terhadap kompetensi guru, berdasarkan hasil uji korelasi Spearman didapatkan hasil Correlation Coefficient sebesar $-0,292$ pada 52 populasi, hasil tersebut termasuk dalam kategori rendah. Berdasarkan hasil tersebut, dapat diketahui nilai signifikansi atau Sig. (2-tailed) sebesar 0,036, karena nilai Sig. (2-tailed) $0,036<$ lebih kecil dari 0,05 maka artinya ada hubungan yang signifikan antara hasil UKG dan pengukuran kadar keguruan. Mengacu pada pembahasan sebelumnya, maka kesimpulan dalam penelitian ini adalah ada hubungan signifikan yang rendah dan negatif antara hasil pengukuran kadar keguruan dan masa kerja yang berdasarkan level (lihat tabel 4). 
Tabel 4. Uji Korelasi Spearman Masa Kerja terhadap Tingkat Kompetensi Guru

\begin{tabular}{lllcc}
\multicolumn{5}{c}{ Correlations } \\
\hline \multirow{4}{*}{ Spearman's rho } & Congukuran & $\begin{array}{c}\text { Pengukuran } \\
\text { Kadar Keguruan }\end{array}$ & $\begin{array}{c}\text { Masa Kerja } \\
\text { (Level) }\end{array}$ \\
\cline { 3 - 4 } & Kadar & Coefficient & 1,000 &,$- 292^{*}$ \\
& Keguruan & Sig. (2-tailed) &. &, 036 \\
& & $\mathrm{~N}$ & 52 & 52 \\
& Correlation &,$- 292^{*}$ & 1,000 \\
& Masa Kerja & Coefficient &, 036 &. \\
& (Level) & Sig. (2-tailed) & 52 & 52 \\
\hline *. Correlation is significant at the 0.05 level (2-tailed). & $\mathrm{N}$ & &
\end{tabular}

Berdasarkan hasil pengukuran kompetensi yang didapat dari UKG tahun 2015 dihubungkan dengan hasil pengukuran kadar keguruan saat ini adalah pengukuran tersebut bisa dilakukan sebagai pengganti pengukuran kompetensi dengan menggunakan UKG. Sedangkan, hasil pengukuran kadar keguruan menunjukkan bahwa tingkat kompetensi guru PJOK di Kecamatan Pogalan dan Kecamatan Bendungan Kabupaten Trenggalek berada pada tingkat baik secara keseluruhan.

\section{Pembahasan}

Berdasarkan hasil pengolahan dan analisis data yang diperoleh dari 24 pertanyaan tentang tingkat kompetensi guru PJOK telah diperoleh jawaban dari 52 responden diperoleh hasil pengukuran kadar keguruan data menunjukkan bahwa guru PJOK yang termasuk dalam kategori buruk $0 \%$ (0 orang), kategori kurang $0 \%$ (0 orang), kategori biasa sebanyak 17,30\% (9 orang), untuk guru PJOK yang termasuk dalam kategori baik termasuk $62,20 \%$ (36 orang), sedangkan untuk guru PJOK yang termasuk dalam kategori hebat sebanyak 13,50\% (7 orang) dari total 52 guru PJOK SD di Kecamatan Pogalan dan Kecamatan Bendungan Kabupaten Trenggalek.

Kompetensi guru dapat memberikan kontribusi atas peningkatan prestasi belajar mampu menjadi teladan aktif kreatif dan mempunyai 
intregritas yang tinggi di sekolah (Marbun, 2015). Setiap kompetensi memiliki korelasi signifikan dengan kompetensi lainnya, artinya setiap kompetensi tidak bisa berdiri sendiri, namun saling melengkapi untuk menghasilkan kompetensi yang berkualitas secara utuh (Lestari \& Purwanti, 2018).

Berdasarkan penelitian ini juga diperoleh hasil bahwa masa kerja juga berpengaruh pada tingkat kompetensi guru PJOK SD yang sesuai dengan hasil pada tabel 4. Melalui masa kerja yang cukup panjang bagi guru diharapkan dapat menjadi tenaga pendidikan yang sukses dalam mengelola kelas yang dibimbingnya (Hasan, 2015). Seiring masa kerja yang lama justru akan mengalami penurunan kompetensi, baik kompetensi pedagogik, profesional, kepribadian, dan sosial (Maksum, 2009). Oleh karena itu diperlukan penyegaran kompetensi pedagogik, profesional, kepribadian dan sosial terutama untuk guru yang masa kerjanya lama.

\section{KESIMPULAN DAN SARAN}

Berdasarkan hasil penelitian yang telah dilakukan tentang Tingkat Kompetensi Guru PJOK dapat disimpulkan bahwa hasil UKG berkaitan erat dengan hasil pengukuran kadar keguruan PJOK, dan masa kerja juga memengaruhi tingkat kompetensi, serta diketahui tingkat kompetensi guru PJOK melalui pengukuran kadar keguruan yang termasuk dalam kategori buruk $0 \%$ (0 orang), kategori kurang $0 \%$ (0 orang), kategori biasa sebanyak 17,30\% (9 orang), untuk guru PJOK yang termasuk dalam kategori baik termasuk 62,20\% (36 orang), sedangkan untuk guru PJOK yang termasuk dalam kategori hebat sebanyak $13,50 \%$ (7 orang) dari total 52 guru PJOK.

Berdasarkan kesimpulan didapat pengukuran dengan menggunakan metode pengukuran kadar keguruan dapat dijadikan sebagai alternatif untuk mengevaluasi sejauh mana tingkat kompetensi guru PJOK, sehingga ke depannya bisa untuk memperbaiki bahkan meningkatkan kompetensi guru sesuai dengan standar yang telah ditetapkan pemerintah. 


\section{REFERENSI}

Fathurrohman, P., \& Suryana, A. (2012). Guru Profesional. Bandung: PT. Refika Aditama.

Hasan, R. (2015). Pengaruh Masa Kerja dan Pendidikan Guru Terhadap Kinerja Guru SDN Sukabumi 10 Kota Probolinggo. Jurnal Penelitian Dan Pendidikan IPS (JPPI), 9(2), 1219-1230. Retrieved from ejournal.unikama.ac.id/index.php/JPPI/article/view/1664

Heywood, D., \& Parker, J. (2010). The pedagogy of physical science (Vol. 38). Dordrecht: Springer.

Jatmika, H. M., Hariono, A., Purwanto, J., \& Setiawan, C. (2017). Analisis kebutuhan guru pendidikan jasmani, olahraga dan kesehatan pasca program guru pembelajar. Jurnal Pendidikan Jasmani Indonesia, 12(1), 1-11. Retrieved from http://journal.uny.ac.id/index.php/jpji

Kementerian Pendidikan dan Kebudayaan Direktorat Jendral Guru dan Tenaga Kependidikan. (2015). Pedoman Pelaksanaan Uji Kompetensi Guru. 1-66. Retrieved from http://gtk.kemdikbud.go.id/files/juknis/10_Pedoman_UKG_10_Septe mber_2015_kirim.pdf

Kusumawati, R. (2017). Faktor-Faktor yang Memengaruhi Rendahnya Nilai Pada Uji Kompetensi Guru (UKG) di SMA Al-Azhar 3 Bandar Lampung Tahun 2015. Universitas Lampung.

Lestari, Y. A., \& Purwanti, M. (2018). Hubungan Kompetensi Pedagogik, Profesional, Sosial, dan Kepribadian Pada Guru Sekolah Nonformal X. JURNAL KEPENDIDIKAN, 2(1), 197-208. Retrieved from https://journal.uny.ac.id/index.php/jk/article/download/10207/pdf\%0 $\mathrm{A} \% \mathrm{OA}$

Maksum, A. (2009). Paradoks Guru Pendidikan Jasmani. Journal of Physical Education and Sport, 1(1), 1-13. Retrieved from http:/jurnal.upi.edu/edutech/view/1030/paradoks-guru-pendidikanjasmani.html

Marbun, F. N. (2015). Kompetensi Guru dalam Peningkatan Prestasi Belajar Pada SMP Negeri dalam Kota Banda Aceh. Jurnal Administrasi Pendidikan Pascasarjana Universitas Syiah Kuala, 3(1), 45-67. Retrieved from www.jurnal.unsyiah.ac.id/JAP/article/view/2524

Rink, J. E. (2013). Measuring teacher effectiveness in physical education. Research Quarterly for Exercise and Sport, 84(4), 407-418. https://doi.org/10.1080/02701367.2013.844018

Rosmawaty. (2016). Standart Mutu dan Profesialisme Guru. Konvensi Nasional Pendidikan Indonesia (KONASPI) VIII, (1), 1103-1108. Retrieved from http://seminars.unj.ac.id/konaspi/file/Prosiding KONASPI VIII 2016.pdf 
Snopek, P., \& Moravcikova, D. (2017). Evaluation of the Project "From Novice Teacher to Teacher Mentor" - Teacher's Work with the Chronically III Pupils. Procedia - Social and Behavioral Sciences, 237(June 2016),

745-750. https://doi.org/10.1016/j.sbspro.2017.02.116

Sugiyono. (2014). Metode Penelitian Pendidikan (Pendekatan Kuantitatif, Kualitatif dan R\&D). Bandung: Penerbit Alfabeta.

Suroto. (2016). Pengembangan Instrumen Pengukuran Kadar Keguruan (Tingkat Kompetensi) Mahasiswa Calon Guru dan Guru PJOK Indonesia. Seminar Nasional Hasil Penelitian Dan Pengabdian Kepada Masyarakat - Subtema: Inovasi Pendidikan, 193-202. Retrieved from http://lppm.unesa.ac.id/semnasppm/prosiding2016/1_Inovasi_Pendi dikan.pdf

Wahyono, P. (2016). Peran Pendidikan Guru. Konvensi Nasional Pendidikan Indonesia (KONASPI) VIII, 862-868. Retrieved from http://seminars.unj.ac.id/konaspi/file/Prosiding KONASPI VIII 2016.pdf 